Saudi Journal of Biomedical Research

Abbreviated Key Title: Saudi J Biomed Res ISSN 2518-3214 (Print) |ISSN 2518-3222 (Online)

Scholars Middle East Publishers, Dubai, United Arab Emirates Journal homepage: https://saudijournals.com/sjbr

\title{
Fertility Index and Percentage Fertility of Momordica charantia Treated Male Wistar Rats
}

\author{
Chibuike Obiandu ${ }^{{ }^{*}}$, Adesua C. Obiandu ${ }^{2}$ \\ ${ }^{1}$ Department of Human Physiology, Faculty of Basic Medical Sciences, University of Port Harcourt, Nigeria \\ ${ }^{2}$ Post Primary Schools Board, Port Harcourt, Rivers State, Nigeria
}

DOI: $10.36348 /$ sjbr.2020.v05i02.001

| Received: 03.02.2020 | Accepted: 11.02.2020 | Published: 14.02.2020

*Corresponding author: Chibuike Obiandu

\section{Abstract}

The effect of Momordica charantia leaf extract was evaluated on male wistar rats. The animals were randomly assigned into three (3) groups of six (6) rats each. Group one (1) served as control and received distilled water. Group two (2) and group three (3) received $200 \mathrm{mg} / \mathrm{kg}$ and $400 \mathrm{mg} / \mathrm{kg}$ of the hydromethanol (20\%:80\%) extract respectively. In the final 10 days of study, the males were co-habited with female rats [1 male:2 females]. Results obtained showed that the extract significantly $(\mathrm{P}<0.05)$ reduced Fertility index and percentage fertility of male rats. Decreased sperm quality previously observed with the extract of $M$. charantia with associated reductions in serum Testosterone level may be responsible for this observation.

Keywords: Momordica charantia, hydromethanol, Fertility Index, wistar rats.

Copyright @ 2020: This is an open-access article distributed under the terms of the Creative Commons Attribution license which permits unrestricted
use, distribution, and reproduction in any medium for non-commercial use (NonCommercial, or CC-BY-NC) provided the original author and source
are credited.
are credited.

\section{INTRODUCTION}

There have been some studies on effects of the extract of Momordica charantia (M. charantia) on some reproductive parameters in wistar rats. In a study [1], the effects of the extracts on the pituitary-testicular axis and sperm production in male rats were assessed and the findings indicated an inhibition of serum Testosterone (T), Luteinizing Hormone (LH) and Follicle Stimulating Hormone (FSH) production. In addition, there was a significant $(p<0.01)$ reduction in sperm number and sperm motility in treated rats. A similar study [2] revealed that $M$. Charantia extract caused marked alterations in the sperm physiology leading to significant reduction in sperm viability and motility. Furthermore, a significant reduction in serum $\mathrm{T}$ was reported in a study [3], following administration of extract of M.charantia without affecting the LH and FSH levels. There were significant reduction in sperm viability, morphology, motility and count. However, most of these findings suggest a relative reduction in these reproductive parameters in normal rats when test groups were compared to control. The changes that occur most times do not lead to hormonal concentrations and sperm measures below the normal ranges. It is therefore necessary to investigate if these reductions would translate to an inability of the male to produce conception in the female. The objective of this study is to determine the effects of leaf extract of $M$. charantia on fertility index and percentage fertility of male wistar rats.

\section{MATERIALS AND METHODS Preparation of Plant extract}

Fresh leaves of $M$. charantia were obtained from Choba community in Obio Akpor Local Government Area of Rivers State, Nigeria.The leaves were washed and dried at room temperature, then blended to fine powder. Soxhlet extraction was done using hydromethanol as solvent.

\section{Animals}

Eighteen adult male Wistar rats bred in the Department of Human Physiology, University of Port Harcourt, Nigeria were used for the experiments. The rats initially weighing between $155-165 \mathrm{~g}$ were randomly divided into 3 groups of 6 rats each. Group A served as control and were given distilled water. Group $\mathrm{B}$ and group C were given $200 \mathrm{mg} / \mathrm{kg}$ bw and $400 \mathrm{mg} / \mathrm{kg}$ bw of the hydromethanol leaf extract respectively. The extracts were administered as single oral doses for 30 days. The animals were allowed free access to their feeds and water.

\section{Fertility Test}

At the end of the $20^{\text {th }}$ day after commencement of extract administration, the experimental animals 
were mated with females (1 male: 2 females) to see whether pregnancy would occur. The males were separated after 10 days cohabitation period in accordance with documented methods [4, 5].The number of pregnant females and viable fetuses were recorded while the weights of fetuses were taken. The fertility index and percentage fertility were calculated using the formulae:

i. $\quad$ Fertility index $=\frac{\text { Number of pregnant females in a group }}{\text { Number of mated females in the group }} \times 100$
ii. $\quad$ Percentage fertility $=\frac{\text { Number of litters in a group }}{\text { Number of litters in control group }} \times 100$

\section{STATISTICAL ANALYSIS}

Results were expressed as mean \pm standard error of mean. Analysis was carried out on SPSS version 21 using analysis of variance (ANOVA). The level of significance was considered at $\mathrm{P}<0.05$.

\section{RESULT} and 2 .
The result of this study is presented in tables 1

Table-1: Fertility index of male rats treated with $M$. charantia extract.

\begin{tabular}{|l|c|c|c|}
\hline Group/ & & Parameters & \\
\cline { 2 - 4 } Extracts (mg/kg) & Copulation index (\%) & Pregnant females (n) & Fertility index \\
\hline Control & 100 & 6 & 100 \\
\hline 200 & 100 & 5 & $83^{*}$ \\
\hline 400 & 100 & 3 & $50^{*}$ \\
\hline
\end{tabular}

Values presented as Mean \pm SEM. $\mathrm{n}=6$. Significant at $[*(\mathrm{P}<0.05)]$ when compared with control.

Table-2: Percentage fertility of male rats treated with $M$. charantia extract.

\begin{tabular}{|l|c|c|c|}
\hline Group/ & & Parameters & \\
\cline { 2 - 4 } Extracts (mg/kg) & No. of live litters & \% Change & \% Fertility \\
\hline Control & $7.52 \pm 0.56$ & 0 & 100 \\
\hline 200 & $5.83 \pm 1.22^{*}$ & -21.60 & $77.53^{*}$ \\
\hline 400 & $3.50 \pm 1.58^{*}$ & -51.60 & $46.54^{*}$ \\
\hline
\end{tabular}

Values presented as Mean \pm SEM. $n=6$. Significant at $[*(\mathrm{P}<0.05)]$ when compared with control.

\section{DISCUSSION}

The effects on the number of mated males/females signifying the copulation index and the number of females which got pregnant as well as the fertility index after 30days of extract administration are highlighted in this study. The males in all groups mated with at least one of the cohabiting females. In the control, all female rats that mated with their male became pregnant giving rise to a fertility index of $100 \%$. For the $200 \mathrm{mg} / \mathrm{kg}$ group, all male rats mated with at least one female but all female except one became pregnant. Although, all males mated with the females in the $400 \mathrm{mg} / \mathrm{kg}$ group, only three became pregnant with a fertility index of $50 \%$. In the number of live births, the control group had higher live births than test groups. The statistically significant $(\mathrm{P}<0.05)$ reductions in fertility index and percentage fertility in test groups when compared to control indicates a declining fertility following the administration of $M$. charantia. Several activities taking place in testis also contribute significantly to fertility. However, decreased numbers of spermatozoa, reduced motility and/or morphologically distorted spermatozoa are predominant causative factors in infertility or disturbed fertility in animals [6].
The sperm count is a very useful test of spermatogenesis having direct association with fertility [7] and is quantitatively maintained by Testosterone and Follicle Stimulating Hormone [8]. Also, motile spermatozoa in adequate concentrations devoid of abnormalities are highly correlated with fertility [9]. In a previous study [3] $M$. charantia reportedly caused a significant reduction of various sperm parameters. The reductions encountered in normal animals may be responsible for the decreased Fertility index and percentage fertility observed in this study.

\section{CONCLUSION}

It was observed that a significant reduction occurred in Fertility index and percentage fertility of male wistar rats treated with leaf extracts of $M$. charantia.

\section{REFERENCES}

1. Yama, O.E., Duru, F.I., Oremosu, A.A., Noronha, C.C., \& Okanlawon, A. (2011). Suppressive effects of Momordica charantia on pituitary-testicular axis and sperm production in male Sprague-Dawley rats International Journal of Medicine and Medical Sciences, 3(12): 353-359.

2. Sheeja, E.J., Ajeet, P., Bigoniya, P., \& Singh, S. (2012). Antifertility activity of Momordica charantia descourt pulp and Seed hydroalcoholic 
extract Journal of Applied Pharmacy, 3(4): 682696

3. Obiandu, C., Nnadozie, A.G., Azubuike, B.S., Achinike., P.N., Okari, K., \& Obiandu, A.C. (2020). Reduction in Some Reproductive Indices of Momordica Charantia Treated Male Wistar Rats. Scholars Journal of Applied Medical Sciences, 8(1): 268-273

4. Khouri, N.A., \& El-Akawi, Z. (2005). Antiandrogenic activity of Ruta graveolens L in male Albino rats with emphasis on sexual and aggressive behavior. Neuroendocrinology Letters. 26: 823-9.

5. Parandin, R., Yousofvand, N., \& Ghorbani, R. (2012). The enhancing effects of alcoholic extract of Nigella sativa seed on fertility potential, plasma gonadotropins and testosterone in male rats. Iranian Journal of Reproductive Medicine, 10(4): 355-362.

6. Chauhan, N.S., \& Dixit, V.K. (2008). Spermatogenesis activity of rhizomes of curculigo orchiodes gaertn on male rats. International Journal of Applied Research Natural product.10:26-31.

7. Nwoke, K.U., Sominiari, A.F., Dapper, V.D., \& Ifedi, C.I. (2015). Methanolic extracts of the fruit of Abelmoschus Esculentus (Okro) causes increase in the serum concentration of some reproductive hormones and decreases total sperm count in male albino wistar rats. European journal of pharmaceutical research, 2(5), 57 -66.

8. Yakubu, M.T. (2006). Aphrodisiac potentials and toxicological evaluation of aqueous extract of Fadogia agrestis Schweininf ex. Hiern) stem in male rats. Ph.D. Thesis. University of Ilorin, Ilorin Nigeria.

9. Aitken, R.J., Best, F.S.M., Warner, P., \& Templeton, A. (1984). A prospective study of the relationship between semen quality and fertility in the case of unexplained infertility. Journal of Andrology, 5:297-303. 